
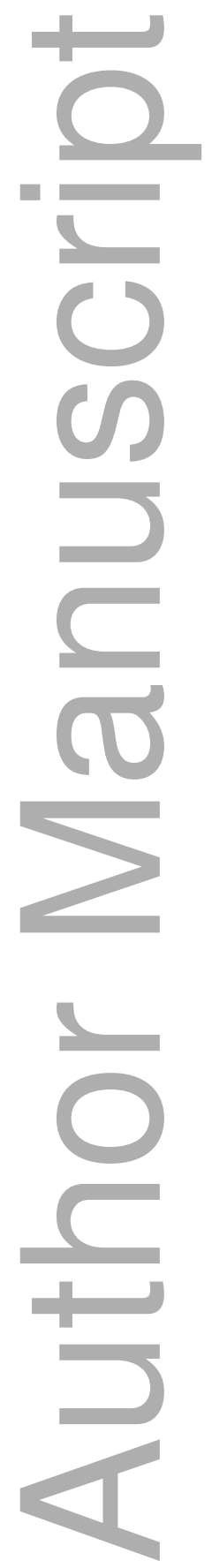

This is the author manuscript accepted for publication and has undergone full peer review but has not been through the copyediting, typesetting, pagination and proofreading process, which may lead to differences between this version and the Version of Record. Please cite this article as doi: $\underline{10.1111 / \text { all.13609 }}$

This article is protected by copyright. All rights reserved 
PROF. MARK HEW (Orcid ID : 0000-0002-7498-0000)

DR. BIRCAN ERBAS (Orcid ID : 0000-0001-9597-418X)

5

6

7

8

Article type : Original Article: Airway Diseases

7

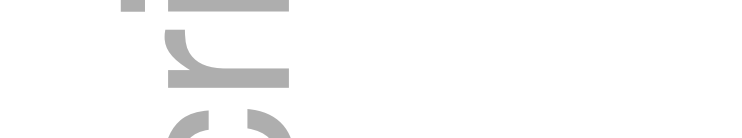

.

\section{The 2016 Melbourne thunderstorm asthma epidemic: risk factors for severe attacks requiring hospital admission}

\section{Corresponding author}

Mark Hew, Allergy, Asthma \& Clinical Immunology, Alfred Health, 55 Commercial Road, Melbourne, Victoria 3004, Australia. Tel +61(0)390762934 Fax +61(0)390762245 Email m.hew@alfred.org.au

\section{Authors}

Mark Hew PhD FRACP ${ }^{1,2}$, Joy Lee MBChB FRACP ${ }^{1}$, Nugroho H Susanto MD ${ }^{3}$, Shivonne Prasad MBChB FRACP ${ }^{4}$, Philip G. Bardin PhD FRACP ${ }^{2,5}$, Sara Barnes MBBS FRACP ${ }^{5}$, Laurence Ruane $\mathrm{BSc}^{5}$, Anne Marie Southcott MBBS FRACP ${ }^{6}$, Andrew Gillman MBBS FRACP ${ }^{6}$, Alan Young PhD FRACP $^{4}$, Kanishka Rangamuwa MBBS ${ }^{4}$, Robyn E O'Hehir PhD FRACP ${ }^{1,2}$, Christine McDonald PhD FRACP $^{7,8}$, Michael Sutherland PhD FRACP ${ }^{7,8}$, Matthew Conron MD FRACP ${ }^{8,9}$, Sarah Matthews $\mathrm{BN}^{9}$, Nur-Shirin Harun MBBS FRACP ${ }^{10}$, Philippe Lachapelle $\mathrm{MD}^{10}$, Jo A Douglass MD FRACP ${ }^{8,10}$, Louis Irving MBBS FRACP ${ }^{8,10}$, David Langton MPH FRACP ${ }^{2,11}$, Jennifer Mann MBBS ${ }^{11}$, Bircan Erbas $\mathrm{PhD}^{3}$, Francis Thien MD FRACP ${ }^{2,4}$.

\section{Affiliations}

${ }^{1}$ Alfred Health, ${ }^{2}$ Monash University, ${ }^{3}$ La Trobe University, ${ }^{4}$ Eastern Health, ${ }^{5}$ Monash Health, ${ }^{6}$ Western Health, ${ }^{7}$ Austin Health, ${ }^{8}$ Melbourne University, ${ }^{9}$ St Vincent's Health, ${ }^{10}$ Melbourne Health, ${ }^{11}$ Peninsula Health. All institutions are in Melbourne, Victoria, Australia.

\section{Contributions}

FT conceived and designed the study, assisted by CM, MS, JAD, JL and MH. All the authors collected the data. FT, MH, JL, NHS, SP, and BE collated and analysed the data. MH wrote the first draft. All the authors wrote the manuscript and approved the final version.

\section{Conflict Statement}

All the authors declare thy have no conflicts relevant to this manuscript.

This article is protected by copyright. All rights reserved 
42 Funding source: None

$43 \quad$ Abstract word count 247

$44 \quad$ Manuscript word count 2621

45

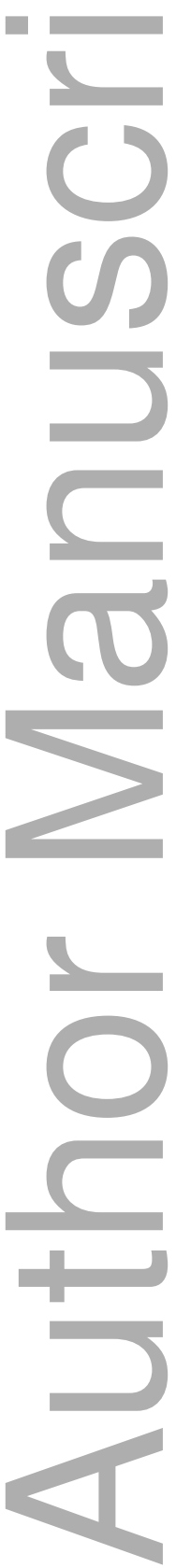

This article is protected by copyright. All rights reserved 
ABSTRACT

Background: The world's most catastrophic and deadly thunderstorm asthma epidemic struck Melbourne, Australia, on November $21^{\text {st }} 2016$.

Objective: Among thunderstorm-affected patients presenting to emergency rooms (ERs), we investigated risk factors predicting severe attacks requiring admission to hospital.

Methods: Thunderstorm-affected patients were identified from ER records at the eight major Melbourne health services and interviewed by telephone. Risk factors for hospital admission were analyzed.

Results: We interviewed 1435/2248 (64\%) of thunderstorm-affected patients, of whom 164 (11.4\%) required hospital admission. Overall, rhinitis was present in $87 \%$, and current asthma in $28 \%$. Odds for hospital admission were higher with increasing age (odds ratio $1.010,95 \%$ 95\% CI 1.26, 2.78]. Prior hospitalization for asthma in the previous 12 months further increased the odds for hospital admission (aOR 3.16, 95\% CI 1.63, 6.12). Among patients of Asian ethnicity, the odds for hospital admission were lower than for non-Asian patients (aOR $0.59,95 \%$ CI 0.38, 0.94), but higher if born in Australia (OR=5.42, 95\% CI 1.56, 18.83).

Conclusions: In epidemic thunderstorm asthma patients who presented to the ER, higher odds for hospital admission among patients with known asthma were further amplified by recent asthma admission, highlighting the vulnerability conferred by suboptimal disease control. Odds for hospital admission were lower in Asian patients born overseas, but higher in Asian patients born locally, than in non-Asian patients; these observations suggest susceptibility to severe thunderstorm asthma may be enhanced by gene-environment interactions. 


\section{Key words}

72 Asthma; thunderstorm; epidemic; emergency; hospitalization; ethnicity; Asian; Indian;

73 rhinitis.

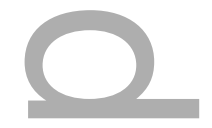

74

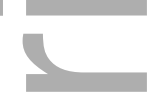

75 Abbreviations

76 ER emergency room

77 SD standard deviation

78 aOR adjusted odds ratio

79 GP general practitioner

80 ACT Asthma Control Test

81 ARIA Allergic Rhinitis and its Impact in Asthma

82

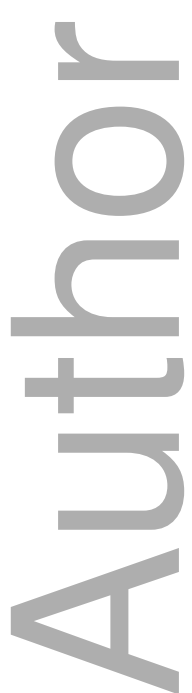

This article is protected by copyright. All rights reserved 
Epidemic thunderstorm asthma occurs when a thunderstorm triggers asthma exacerbations in

85 multiple individuals. Such events strike unexpectedly and with devastating suddenness. The largest and most catastrophic of these occurred on November $21^{\text {st }} 2016$ in Melbourne, Australia $(1,2,3)$. After the storm struck at $6 \mathrm{pm}$, more than 3500 patients across the state of Victoria presented in respiratory distress to Emergency Rooms (ERs), overwhelming ambulance and health services $(4,5)$. Countless more individuals were managed in the community by general practices and pharmacies. Ten deaths have been traced to this epidemic, far exceeding global mortality rates of single reported deaths in three earlier epidemics $(6,7,8)$.

The pathogenesis of thunderstorm asthma is multifactorial. Meteorological factors combine synergistically with high aeroallergen loads to trigger bronchospasm in susceptible individuals $(9,10)$. Culprit allergens vary across the globe. The allergen implicated in epidemics occurring in South-eastern Australia is ryegrass pollen $(6,11,12)$ with all six previous Melbourne epidemics also occurring in November, during the peak of ryegrass pollination $(6,13,14,15)$. The 2016 event also recorded extreme levels $(102$ grains/m3 of airborne pollen on the day $(16,17)$. (Increased particulate matter $\left(\mathrm{PM}_{10}\right)$ concentrations at the time were associated with a gust front and constituted a raised dust event, most likely incidental (17).)

Individual susceptibility factors that have been identified in previous Australian epidemics are: allergic rhinitis; ryegrass pollen sensitization; pre-existing asthma; poor adherence to corticosteroid-based preventers; and, outdoor location at the time of the storm $(11,12)$. The relevance of ryegrass pollen sensitization, seasonal allergic rhinitis, and outdoors exposure was again confirmed for the 2016 Melbourne epidemic, occurring in 100\%, 99\%, and 94\% 
respectively among patients from a single centre (16). However, the small size and restricted datasets of the cohorts limit their conclusions.

We recently reported that the 2016 Melbourne epidemic featured an ethnic predominance of Asian and Indian patients among ER presentations, hospital admissions, and fatal cases (17); possible explanations for this include higher rates of atopy, or socio-cultural barriers to medical care. Also, while the majority of thunderstorm asthma patients did not have a prior diagnosis of asthma, all patients admitted to intensive care had known asthma (17).

114 To further explore individual susceptibility to epidemic thunderstorm asthma, and in 115 particular to severe acute attacks, we sought to identify risk factors for hospital admission from the ER. We studied patients who presented to ERs of the eight Melbourne metropolitan

117 health networks and subsequently undertook structured telephone interviews.

\section{Methods}

\section{Clinical follow-up}

Hospital ERs were overwhelmed by thunderstorm asthma presentations on the 21 st of November 2016, and no site was able to immediately organize appropriate follow-up for assessed patients.

The eight Melbourne metropolitan health services collaborated to develop a unified approach. Each Respiratory Department obtained full lists of all ER presentations with respiratory symptoms at their institution between the $21^{\text {st }}$ and $23^{\text {rd }}$ of November, 2017. Each patient's record was reviewed to confirm consistency with acute asthma and to exclude alternative

127 diagnoses. A clinical questionnaire was developed. Medical staff and trained medical students under supervision telephoned all affected patients. This occurred 3-4 weeks after the 
thunderstorm event between the $12^{\text {th }}$ and $23^{\text {rd }}$ of December, 2016. Based on telephone responses and according to individual local resources, patients were appropriately triaged to attend urgent clinic review.

\section{Clinical telephone questionnaire.}

There are no validated telephone questionnaires for use in thunderstorm asthma epidemics. A questionnaire was therefore devised to determine the following: whether patients were still symptomatic at the time of the phone call (high-risk: urgent review); age and gender; selfidentified ethnicity; birthplace; whether they had perennial or seasonal rhinitis and its severity (18); their main location during the afternoon and evening (outdoors vs indoors; windows open or shut); whether they had previously been diagnosed with asthma, and; if known to have asthma, to what degree their asthma had been controlled prior to the thunderstorm event (based on the Asthma Control Test, used with permission) (19), use of inhaled corticosteroid preventers, possession of asthma action plans, and previous health care utilization; if not known to have asthma, whether they had symptoms suggesting undiagnosed asthma prior to the thunderstorm event; concurrent allergic conditions; and smoking status.

\section{Data compilation, comparison, and analysis}

Following the conclusion of the clinical triaging protocol, approval from all eight individual Institutional Review Boards was sought to retrieve, analyze, and combine data from multiple sites in order to inform government public health policy (4) and for scientific publication. Non-identifiable data were pooled from all sites for combined analysis. Baseline demographics of this cohort have been previously published (17).

\section{Patient characteristics}


151 The characteristics of patients discharged home from the ER were compared to those who 152 were admitted to hospital.

\section{Risk factors for hospital admission}

Descriptive data are presented as frequencies and percentages for categorical data and mean

(SD) for continuous. Demographic and clinical characteristics of those admitted to hospital

and those discharged home from the ER were compared using t-tests for continuous variables and chi-square or Fisher's exact tests for categorical variables.

Logistic regression methods were used to assess risk factors for outcomes defined as hospital admission (yes, no). Both unadjusted and age, sex adjusted models were fitted to each outcome. Multivariate logistic regression models with all possible risk factors, age and sex adjustments were also considered.

Interaction terms were included in the regression models if there were evidence of an effect modification from any of the risk factors. Interaction terms were considered statistically significant if $\mathrm{p}<0.1$.

Results are presented as odds ratios with $95 \%$ confidence intervals with $p<0.05$ considered statistically significant. Analyses were performed using Stata, release 12.0 (StataCorp,

\section{College Station, TX).}

Patients were identified and contacted as previously published (17). Of 2242 records of thunderstorm presentations, usable interview data were obtained for 1435 patients (64\%). 
172 [The other 807 patients were either uncontactable despite repeated phone calls (679),

173

174

175 declined to participate (105) or provided uninterpretable data (23).] Of the 1435 patients analyzed, $164(11.4 \%)$ required hospital admission, and the rest were discharged directly from the ER.

The patient cohort had a mean age of 32.0 years (standard deviation \pm 18.6 years) and a male predominance (56\%, Table 1). Current smoking was uncommon (8\%). As reported in our previous publication, Asian (Chinese, Vietnamese, East or South-East Asian- 22\%) and Indian (includes Sri Lankan, Pakistani and Bangladeshi-17\%) ethnicity were over-represented in this cohort, when compared to census-derived combined Asian and Indian ethnicity of $25 \%$ in the resident population (Table 1) (17). Exactly half the cohort was born in Australia. Sixtyeight percent reported exposure to the outdoors (either physically outdoors, or indoors with open windows).

Known current asthma was present in $28 \%$, past asthma in $15 \%$, and symptoms suggestive of undiagnosed asthma (wheeze, chest tightness or shortness of breath) in $26 \%$ (Table 2).

Eighty-seven percent reported symptoms of seasonal allergic rhinitis (runny nose, sneezing, blocked itchy nose, watery itchy eyes) involving at least the springtime. Seventy-two percent had moderate or severe rhinitis symptoms based on established criteria (18). Self-reported eczema (28\%) and food allergy (16\%) were less common (Table 2).

Among patients with current asthma, symptoms were not well controlled in 55\% (Table 3). Fifty-eight percent of those with current asthma did not have an action plan. Sixty-eight percent either were not prescribed a corticosteroid preventer prior to the thunderstorm, or were using this less than five days per week. Health care utilization among current asthma patients in the prior 12 months is summarized in Table 3, and indicated low rates of non- 
urgent primary care review, and high rates of ER presentations and overnight hospital admissions.

\section{Risk factors for hospital admission}

Among the entire cohort, patients with known current asthma had increased odds of admission to hospital wards or intensive care [adjusted odds ratio (aOR) 1.87, 95\% CI 1.26,

2.78,]. Increasing age and increasing numbers of years in Australia were also associated with higher odds of requiring hospital admission. Asian ethnicity appeared to reduce the odds of hospital admission (aOR 0.59,95\% CI 0.38, 0.94, Table 4).

Because birthplace in Australia was near significance for an increased risk for hospital admission (aOR 1.44, p=0.05, Table 4) we further stratified data by place of birth (Table 5). Asian patients born overseas (first generation migrants) had a lower odds of admission $(\mathrm{aOR}=0.33,95 \% \mathrm{CI} 0.13,0.85)$. An interaction analysis of Asian ethnicity and birth place showed a higher odds of admission for Asian patients born locally in Australia (aOR=5.42, $95 \%$ CI 1.56, 18.83).

Patients of Indian ethnicity did not have these risk-profile interactions with birthplace (data not shown).

Among patients with known current asthma, hospital admission in the prior 12 months was associated with higher odds of hospital admission for thunderstorm asthma (aOR 3.16, 95\%

213 CI 1.63, 6.12, Table 6). The possession of an asthma action plan increased the odds for hospital admission (aOR 2.7595\% CI 1.51, 5.00), while self-reported food allergy reduced the odds for admission (aOR 0.31, 95\% CI 0.13, 0.76) (Table 6).

\section{Discussion}


The 2016 Melbourne thunderstorm epidemic asthma event was the largest and most catastrophic to date (17). Among patients who presented to ER during the epidemic, our analysis indicates that age, current asthma, ethnicity, and birthplace, all influence the likelihood of a severe acute attack requiring hospital admission. These findings have wideranging practical implications for public health messaging, preventive health policy, and clinical management. They also extend our understanding of the pathophysiology of epidemic thunderstorm asthma and the underlying patterns of allergic disease.

Our initial investigation into the 2016 Melbourne epidemic suggested that patients of Asian (Chinese, Vietnamese, East or South-East Asian) and Indian subcontinental ethnicity were over-represented among ER presentations, among those admitted to hospital, and also among ten deaths related to the epidemic and under coronial investigation (17).

Conflicting factors around ethnicity may impact ER presentations for asthma. On one hand, ethnic minorities are often substantially composed of migrants, who usually have a lower prevalence of asthma $(20,21,22)$. On the other hand, ethnic minorities face disparities in asthma burden (23), quality of asthma care $(24,25)$, and even inclusion in asthma trials (26). Thus the previous observation that Asian and Indian minorities were over-represented in the recent thunderstorm asthma epidemic (17) could relate to social and cultural factors impeding effective planned asthma care, and predisposing to increased unplanned ER presentations.

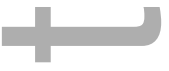

This current analysis uncovers a more complex and nuanced relationship between ethnicity and thunderstorm asthma risk, due to an interaction with birthplace. We found that firstgeneration Asian migrants presenting to ER with thunderstorm asthma had lower odds for severe attacks requiring hospital admission when compared to patients of Caucasian, or other, ethnicity. This is consistent with the previously-described healthy migrant effect (20). We additionally found, however, that Asian patients born locally in Australia had higher odds for 
241 severe attacks requiring hospital admission. This is unlikely to be explained by socio-cultural

242 factors, since second and subsequent-generation Asian migrants might be expected to have overcome socio-cultural barriers to good health care. Australian-born status would be

244 expected to confer protection from admission rather than increased risk. We therefore postulate that the increased odds for hospitalization among Australian-born Asians are more consistent with a gene-environment interaction and conceivably incremental sensitization to rye grass pollen.

It is known that second generation migrants are often reported to have a higher prevalence of asthma than first generation migrants (20). This has been specifically shown among Asian immigrants in Melbourne (27). In the same study, the prevalence of atopy and allergic rhinitis in Asians, whether born overseas or in Australia, exceeded that observed in non-Asians (27). Against this background, first generation Asian migrants may have an (initially) dormant genetic susceptibility toward greater severity of thunderstorm-related asthma attacks, which becomes activated in subsequent generations by early life environmental exposures occurring in the host country.

In further support of this hypothesis, multiple ethnic-specific gene-environment interactions relating to atopic disease have been reported (28). Differences in asthma genetics are also present between Chinese and other populations (29). Epigenetic mechanisms such as DNA methylation may explain how environmental conditions influence the expression of allergy and asthma genes (30). Our findings are also concordant with the pattern of non-respiratory allergic conditions in Australia, where Asian-born children have a lower prevalence of nut allergy than their Australian-born counterparts, but Asian children born in Australia have an increased prevalence compared to non-Asian children $(31,32)$. With increasing globalization and migration trends from the developing world to developed nations, our findings have 
implications for the prevention, detection, and treatment of allergic diseases beyond epidemic thunderstorm asthma.

The risk profiles related to Asian ethnicity in this analysis did not extend to patients of Indian sub-continental ethnicity. It is possible that the two ethnic groups may have a different susceptibility to relevant gene-environment interactions, although there are currently no data to support this hypothesis. Different migration patterns may offer another explanation for our finding, as proportionally fewer patients of Indian ethnicity (16\%) than Asian ethnicity (24\%) were born in Australia.

An increased number of years spent in Australia, and increasing age, were also associated with a higher risk of hospitalization. The former may reflect increasing vulnerability with progressive environmental exposure among first-generation migrants. The latter suggests that thunderstorm asthma attacks may be treated more easily in children, and be more rapidly responsive to therapy.

A second major risk factor for hospital admission from the ER in this analysis was a known current asthma diagnosis. This suggests that although individuals without a prior asthma diagnosis (comprising $56 \%$ of our total cohort) are vulnerable to thunderstorm asthma, patients with known current asthma are at greater risk of a severe attack requiring admission. This may possibly relate to a greater degree of bronchial hyper-reactivity present in those with known current asthma. In addition, we found that patients with an overnight hospital admission in the previous 12 months were at even higher risk. This is consistent with our prior observation during the 2016 epidemic, that all 35 patients admitted to Victorian intensive care units had a known diagnosis of asthma (17). Taken together, it could be argued that the most effective approach in Australia to mitigate the danger of epidemic thunderstorm asthma lies in focusing on the known asthmatic population, and addressing existing gaps in 
asthma care delivery $(33,34)$. Such measures would also deliver the substantial benefit of reducing all asthma mortality, still approximating 400 Australian lives per year (35).

The finding that possessing an action plan increased the odds for admission among known asthmatics was not unexpected. It is likely to reflect higher possession of action plans among patients with poor asthma control or recent hospitalization. The finding of lower odds for admission among patients reporting food allergy may be due to unmeasured confounding factors.

Our study confirmed the presence of allergic rhinitis in the overwhelming majority of patients presenting to ERs, similar to previous Australian reports $(6,12,36)$. In communities vulnerable to thunderstorm asthma, this highlights the need for allergic rhinitis management to be carefully optimised, with measures including intranasal corticosteroids and specific allergen immunotherapy for grass-pollen allergy $(37,38)$.

We also found a low prevalence of smoking, again consistent with previous epidemics $(12,39)$. Exposure to the outdoors did not appear to increase the risk of hospital admission, but this may reflect our questionnaire design; patients were asked where they spent most of the afternoon or evening, rather than whether they had any outdoors exposure or known direct exposure during the event.

The cohort comprised $40 \%$ of the estimated 3500 ER thunderstorm presentations across the state of Victoria, but $64 \%$ of all presentations to our eight metropolitan health services. Baseline demographic data from the Department of Health (4) of total ER presentations showing near identical mean age and gender distribution with our cohort give assurance that our data are representative of all cases affected by the 2016 Melbourne epidemic. We have interpreted the need for hospital admission from the ER to reflect a greater severity of acute 
312 asthma (40). However, factors other than asthma acuity, including ethnicity, can also

313 influence the clinical decision to admit from the ER (41). While we examined individual

314

315

316

317

318

319

320

322

323

324

325

susceptibility for hospital admission due to thunderstorm asthma, we were unable to take into account variability in exposure due to local meteorological conditions, or the timing, intensity, and duration of exposure to airborne allergens.

$\square$

We further acknowledge that the estimated confidence interval are wide for the interaction analysis of Asian born in Australia $(\mathrm{aOR}=5.42,95 \%$ CI 1.56, 18.83) but note that the $\mathrm{p}$ value for the interaction term is highly significant $\mathrm{p}=0.008$. As this is a discovery our findings should ideally be validated in another cohort that experienced epidemic thunderstorm asthma. But this is somewhat challenging because other thunderstorm asthma event studies may not have similar information about ethnicity. Our ethnicity strata sample size is small which raises the possibility of a power issue. Residual confounding may also be likely with small group stratification due to sampling error. We have as best possible, adjusted for possibly important confounding but acknowledge that it may not eliminate it due to unknown or unincluded confounders (socioeconomic status, educational level or psychological comorbidity). Despite this possibility, we still found significant effects of an interaction term between ethnicity and born in Australia.

In conclusion, current asthma and previous hospitalization for asthma are compounding risk factors for hospital admission due to epidemic thunderstorm asthma. In addition, contrasting findings in first-generation Asian migrants and Australian-born Asian individuals suggest that gene-environment interactions may increase risk. These patient groups should be identified and targeted in public health education and preventative strategies. 
The following staff and medical student volunteers generously assisted in facilitating the clinical follow-up of emergency room patients, which subsequently provided data for this study: Jennifer Mann (Peninsula Health), Sarah Matthews (St Vincent's Health), Caroline Kronborg (Alfred Health), Maree Barnes (Austin Health), Sarah Calvert, Rowena Cao, Philip Chan, Robbie Chan, Gordon Chen, Ernest Cheung, Ruby Cleeland, Anthony Cocco, Emma

Cole, Stephanie Davies, Alfredo de Faria, Kathryn Claire Demase, Yomna Elsamman,

Fangbo (Peter) Ge, Kai-Xing Goh, Georgia Goulopoulos, Navya Gullapalli, Eda Arife

Gungormez, Nathan Hanegbi, Evangelia Haralabopoulos, Theoni Haralabopoulos, Shasha

Haycock, Maria Hormiz, Angus Hughes, Danielle Hulse, Alaric Indranada, Rahul Ingle,

Mourushi N Isa, Arushi Jain, Merav Katz, Afnan Khaleque, Skye Kinder, Nadja Korajkic,

Varuna Kurnauth, Ruth Lai, Andrew Lanyon, Tina Le, Dana Yen Lin Lee, Jeffrey Lee,

Jeremy Lee, Andy Leung, Xinyu Liang, Linly Liu, Vivian Ly, Camilla Malmgren, Laura

McDonald-Wedding, Evan McRobb, Kikie Miu, Rowena Mortimer, Rhea Navani, Tuzana

Nawar, Julie Nguyen, Nik Nur Fathiyah Nik Mohd Nasir, Julien Nithianandan, Subashree

Paramasivam, Jennifer Phan, Tehreem Rawal, Lucinda Roberts, Blake Roschach, Natalie

Saerian, Yasmin Shvartz, William Sim, Daniel Sinnott, Lai Soo, Jessica Stark, James

Sutherland, Neri Tan, Mary Teo, Aimy Tran, Jonathan Tsiglopoulos, Evan Urquhart, Jenny

Wang, Joan Wang, Chloe Wong, Wesley Wong, Calvin Wu, Catherine Yu, Shane Zaw, Zoe

Zhou.

\section{References}

1. Hew M, Sutherland M, Thien F, O'Hehir R. The Melbourne thunderstorm asthma event: can we avert another strike? Intern Med J. 2017;47(5):485-7. attacks. J Allergy Clin Immunol. 2017 Jun;139(6):1786-1787. 
3. Sutherland MF, Portelli EL, Collins AL, Rahman MA, McDonald CF, A comparison of patients with thunderstorm asthma and severe asthma in Melbourne, Med J Australia 2017 Nov 20;207(10):434-435.

4. Chief Health Officer. The November 2016 Victorian epidemic thunderstorm asthma event: an assessment of the health impacts. In: Services DoHaH, editor: Victorian Government, Department of Health and Human Services, April 2017

5. Andrew E, Nehme Z, Bernard S, Abramson MJ, Newbigin E, Piper B, Dunlop J, Holman P, Smith K. Stormy weather: a retrospective analysis of demand for emergency medical services during epidemic thunderstorm asthma. BMJ. 2017 Dec 13;359:j5636.

6. Bellomo R, Gigliotti P, Treloar A, Holmes P, Suphioglu C, Singh MB, et al. Two consecutive thunderstorm associated epidemics of asthma in the city of Melbourne. The possible role of rye grass pollen. Med J Aust. 1992;156(12):834-7.

7. Venables KM, Allitt U, Collier CG, Emberlin J, Greig JB, Hardaker PJ, Highham JH, LaingMorton T, Maynard RL, Murray V, Strachan D, Tee RD. Thunderstorm-related asthma--the epidemic of 24/25 June 1994. Clin Exp Allergy. 1997 Jul;27(7):725-36.

8. Pulimood TB, Corden JM, Bryden C, Sharples L, Nasser SM. Epidemic asthma and the role of the fungal mold Alternaria alternata. J Allergy Clin Immunol. 2007;120(3):610-7.

9. D'Amato G, Vitale C, D'Amato M, Cecchi L, Liccardi G, Molino A, et al. Thunderstorm-related asthma: what happens and why. Clin Exp Allergy. 2016;46(3):390-6.

10. Marks GB, Colquhoun JR, Girgis ST, Koski MH, Treloar AB, Hansen P, et al. Thunderstorm outflows preceding epidemics of asthma during spring and summer. Thorax. 2001;56(6):468-71.

11. Suphioglu C, Singh MB, Taylor P, Bellomo R, Holmes P, Puy R, et al. Mechanism of grasspollen-induced asthma. Lancet. 1992;339(8793):569-72.

12. Girgis ST, Marks GB, Downs SH, Kolbe A, Car GN, Paton R. Thunderstorm-associated asthma in an inland town in south-eastern Australia. Who is at risk? Eur Respir J. 2000;16(1):3-8.

13. Egan P. Weather or not. Med J Aust. 1985 Mar 4;142(5):330.

14. Howden ML, McDonald CF, Sutherland MF. Thunderstorm asthma--a timely reminder. Med J Aust. 2011 Nov 7;195(9):512-3.

15. Erbas B, Akram M, Dharmage SC, Tham R, Dennekamp M, Newbigin E, Taylor P, Tang ML, Abramson MJ. The role of seasonal grass pollen on childhood asthma emergency department presentations. Clin Exp Allergy. 2012 May;42(5):799-805.

16. Lee J, Kronborg C, O’Hehir RE, Hew M. Who's at risk of thunderstorm asthma? The ryegrass pollen Trifecta and lessons learnt from the Melbourne thunderstorm epidemic. Respir Med. 2017 November; 132:146-148

17. Thien F, Beggs PJ, Csutoros D, Darvall J, Hew M, Davies JM, et al. The Melbourne epidemic thunderstorm asthma event 2016: an investigation of environmental triggers, effect on health services, and patient risk factors. The Lancet Planetary Health 2018;2(6):e255-e263. DOI: https://doi.org/10.1016/S2542-5196(18)30120-7. 
18. Bousquet J, Khaltaev N, Cruz AA, Denburg J, Fokkens WJ, Togias A, et al. Allergic Rhinitis and its Impact on Asthma (ARIA) 2008 update (in collaboration with the World Health Organization, GA(2)LEN and AllerGen). Allergy. 2008;63 Suppl 86:8-160.

19. Nathan RA, Sorkness CA, Kosinski M, Schatz M, Li JT, Marcus P, Murray JJ, Pendergraft TB. Development of the Asthma Control Test: a survey for assessing asthma control. J Allergy Clin Immunol. 2004 Jan;113(1):59-65.

20. Cabieses B, Uphoff E, Pinart M, Antó JM, Wright J. A systematic review on the development of asthma and allergic diseases in relation to international immigration: the leading role of the environment confirmed. PLoS One. 2014 Aug 20;9(8):e105347

21. Garcia-Marcos L, Robertson CF, Ross Anderson H, Ellwood P, Williams HC, Wong GW; ISAAC Phase Three Study Group. Does migration affect asthma, rhinoconjunctivitis and eczema prevalence? Global findings from the international study of asthma and allergies in childhood. Int J Epidemiol. 2014 Dec;43(6):1846-54.

22. Yao J, Sbihi H. Prevalence of non-food allergies among non-immigrants, long-time immigrants and recent immigrants in Canada. Can J Public Health. 2016 Dec 27;107(4-5):e461-e466.

23. Forno E, Celedón JC. Health disparities in asthma. Am J Respir Crit Care Med. 2012 May $15 ; 185(10): 1033-5$.

24. Cabana MD, Lara M, Shannon J. Racial and ethnic disparities in the quality of asthma care. Chest. 2007 Nov;132(5 Suppl):810S-817S.

25. Thakur N, Barcelo NE, Borrell LN, Singh S, Eng C, Davis A, Meade K, LeNoir MA, Avila PC, Farber HJ, Serebrisky D, Brigino-Buenaventura E, Rodriguez-Cintron W, Thyne S, RodriguezSantana JR, Sen S, Bibbins-Domingo K, Burchard EG. Perceived Discrimination Associated With Asthma and Related Outcomes in Minority Youth: The GALA II and SAGE II Studies. Chest. 2017 Apr;151(4):804-812.

26. Radhakrishna N, Hew M. Addressing ethnic disparity in asthma trials. Respirology. 2014 Aug;19(6):775-6.

27. Leung RC, Carlin JB, Burdon JG, Czarny D. Asthma, allergy and atopy in Asian immigrants in Melbourne. Med J Aust. 1994 Oct 3;161(7):418-25.

28. Gupta J, Johansson E, Bernstein JA, Chakraborty R, Khurana Hershey GK, Rothenberg ME, Mersha TB. Resolving the etiology of atopic disorders by using genetic analysis of racial ancestry. J Allergy Clin Immunol. 2016 Sep;138(3):676-699.

29. Leung TF, Ko FW, Sy HY, Tsui SK, Wong GW. Differences in asthma genetics between Chinese and other populations. J Allergy Clin Immunol. 2014 Jan;133(1):42-8.

30. Prescott S, Saffery R. The role of epigenetic dysregulation in the epidemic of allergic disease. Clin Epigenetics. 2011 Aug;2(2):223-232.

31. Koplin JJ, Peters RL, Ponsonby AL, Gurrin LC, Hill D, Tang ML, Dharmage SC, Allen KJ; HealthNuts Study Group.Increased risk of peanut allergy in infants of Asian-born parents compared to those of Australian-born parents. Allergy. 2014 Dec;69(12):1639-47. 

JK, Vicendese D, Erbas B, Matheson MC, Tang ML, Douglass J, Ponsonby AL, Dwyer T, Goldfeld S, Allen KJ. Nut allergy prevalence and differences between Asian-born children and Australian-born children of Asian descent: a state-wide survey of children at primary school entry in Victoria, Australia. Clin Exp Allergy. 2016 Apr;46(4):602-9.

33. Reddel HK, Sawyer SM, Everett PW, Flood PV, Peters MJ. Asthma control in Australia: a crosssectional web-based survey in a nationally representative population. Med J Aust. 2015 May

$443 \quad 18 ; 202(9): 492-7$.

444 34. Tay TR, Abramson MJ, Hew M. Closing the million patient gap of uncontrolled asthma. Med J 445 Aust. 2016 Apr 4;204(6):216-7

35. AIHW. Allergic rhinitis ('hay fever') in Australia Canberra: AIHW. 2011 [Viewed 26 May 2017]. Cat. no. ACM 23. : Available from: http://www.aihw.gov.au/publication-detail/?id=10737420595.

36. Wark PA, Simpson J, Hensley MJ, Gibson PG. Airway inflammation in thunderstorm asthma. Clin Exp Allergy. 2002 Dec;32(12):1750-6.

37. Davies JM, Thien F, Hew M. Thunderstorm asthma: controlling (deadly) grass pollen allergy. BMJ. 2018;360:k432.

38. O'Hehir RE, Varese NP, Deckert K, Zubrinich CM, van Zelm MC, Rolland JM, Hew M. Epidemic Thunderstorm Asthma Protection with Five-grass Pollen Tablet Sublingual

454 Immunotherapy.Am J Respir Crit Care Med. 2018 Feb 20. doi: 10.1164/rccm.201711-2337LE. [Epub 455 ahead of print]

39. Forouzan A, Masoumi K, Haddadzadeh Shoushtari M, Idani E, Tirandaz F, Feli M, Assarehzadegan MA, Asgari Darian A. An overview of thunderstorm-associated asthma outbreak in southwest of Iran. J Environ Public Health. 2014;2014:504017.

40. Pollack CV Jr, Pollack ES, Baren JM, Smith SR, Woodruff PG, Clark S, Camargo CA; Multicenter Airway Research Collaboration Investigators. A prospective multicenter study of patient factors associated with hospital admission from the emergency department among children with acute asthma. Arch Pediatr Adolesc Med. 2002 Sep;156(9):934-40 prospective multicenter study of factors associated with hospital admission among adults with acute asthma. Am J Med. 2002 Oct 1;113(5):371-8.

466

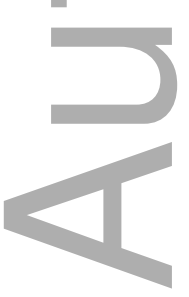


Table 1. Demographics of thunderstorm asthma patients by Emergency Room disposition

\begin{tabular}{|c|c|c|c|c|c|c|c|}
\hline \multirow{2}{*}{ Age (Mean, SD) } & \multicolumn{2}{|c|}{$\begin{array}{l}\text { All ER patients } \\
(\mathrm{n}=1435)\end{array}$} & \multicolumn{2}{|c|}{ Discharged home $(n=1271)$} & \multicolumn{2}{|c|}{ Admitted to hospital $(n=164)$} & \multirow{2}{*}{$\frac{\mathrm{p} \text { value }}{0.06}$} \\
\hline & 31.9 & 18.5 & 31.6 & 17.8 & 35.1 & 23.5 & \\
\hline \multirow[t]{3}{*}{ Sex } & $\mathrm{n}$ & $\%$ & $\mathrm{n}$ & $\%$ & $\mathrm{n}$ & $\%$ & 0.34 \\
\hline & 636 & 44 & 569 & 45 & 67 & 41 & \\
\hline & 799 & 56 & 702 & 55 & 97 & 59 & \\
\hline \multirow{5}{*}{$\begin{array}{ll}\text { Smoking } & \\
& \text { Never } \\
\text { Past } \\
\text { Current } \\
\text { Unknown }\end{array}$} & $\mathrm{n}$ & $\%$ & $\mathrm{n}$ & $\%$ & $\mathrm{n}$ & $\%$ & 0.97 \\
\hline & 934 & 65 & 828 & 65 & 106 & 65 & 0.99 \\
\hline & 340 & 24 & 300 & 24 & 40 & 24 & \\
\hline & 122 & 8 & 108 & 8 & 14 & 9 & \\
\hline & 39 & 3 & 35 & 3 & 4 & 2 & \\
\hline \multirow{7}{*}{$\begin{array}{l}\text { Ethnicity } \\
\text { Caucasian } \\
\text { Asian } \\
\text { Indian } \\
\text { Aboriginal or Torres Strait Islander } \\
\text { Other } \\
\text { Unknown }\end{array}$} & $\mathrm{n}$ & $\%$ & $n$ & $\%$ & $\mathrm{n}$ & $\%$ & 0.29 \\
\hline & 544 & 38 & 475 & 37 & 69 & 42 & \\
\hline & 320 & 22 & 293 & 23 & 27 & 16.5 & \\
\hline & 239 & 17 & 209 & 16 & 30 & 18 & \\
\hline & 10 & 1 & 8 & 0.6 & 2 & 1.4 & \\
\hline & 146 & 10 & 131 & 10 & 15 & 9 & \\
\hline & 176 & 12 & 155 & 12 & 21 & 13 & \\
\hline Born in Australia & $\mathrm{n}$ & $\%$ & $\mathrm{n}$ & $\%$ & $\mathrm{n}$ & $\%$ & 0.44 \\
\hline Yes & 723 & 50 & 636 & 50 & 87 & 53 & \\
\hline No & 698 & 49 & 623 & 49 & 75 & 46 & \\
\hline Unknown & 14 & 1 & 12 & 0.9 & 2 & 1 & \\
\hline \multirow{5}{*}{$\begin{array}{l}\text { Outdoors } \\
\text { Indoors with open windows } \\
\text { Indoors closed windows } \\
\text { Unknown }\end{array}$} & $\mathrm{n}$ & $\%$ & $\mathrm{n}$ & $\%$ & $\mathrm{n}$ & $\%$ & 0.71 \\
\hline & 518 & 36 & 463 & 36 & 55 & 33.5 & \\
\hline & 464 & 32 & 410 & 32 & 54 & 33 & \\
\hline & 431 & 30 & 378 & 30 & 53 & 32 & \\
\hline & 22 & 2 & 20 & 1.6 & 2 & 1.2 & \\
\hline
\end{tabular}

469 ER: Emergency Room. SD: standard deviation. Asian: Chinese, Vietnamese, East or South-East Asian. Indian: also includes Sri-Lankan, Pakistani and Bangladeshi 
Table 2 Asthma and allergic disease status of thunderstorm asthma patients by Emergency Room disposition.

\begin{tabular}{|c|c|c|c|c|c|c|c|c|}
\hline \multirow[t]{2}{*}{ 1 } & & \multicolumn{2}{|c|}{$\begin{array}{l}\text { All ER patients } \\
(\mathrm{n}=1435)\end{array}$} & \multicolumn{2}{|c|}{$\begin{array}{c}\text { Discharged home } \\
(\mathrm{n}=1271)\end{array}$} & \multicolumn{2}{|c|}{$\begin{array}{l}\text { Admitted to hospital } \\
\quad(\mathrm{n}=164)\end{array}$} & \multirow[t]{2}{*}{$\mathrm{p}$ value } \\
\hline & & $\mathrm{n}$ & $\%$ & $\mathrm{n}$ & $\%$ & $\mathrm{n}$ & $\%$ & \\
\hline Asthma status & & & & & & & & $\mathbf{0 . 0 0 3}$ \\
\hline Known asthma & Current asthma (symptoms in prior 12 months) & 395 & 28 & 337 & 27 & 58 & 35 & \\
\hline \multirow{3}{*}{ No known asthma } & Past asthma (symptoms $>12$ months prior) & 210 & 15 & 189 & 15 & 21 & 13 & \\
\hline & Symptoms suggesting undiagnosed asthma & 369 & 26 & 319 & 25 & 50 & 30 & \\
\hline & Never had asthma symptoms & 424 & 30 & 394 & 31 & 30 & 18 & \\
\hline Unknown & & 10 & 0.7 & 9 & 0.7 & 1 & 0.6 & \\
\hline \multirow{6}{*}{ Allergic rhinitis } & Any & 1249 & 87 & 1112 & 87.5 & 137 & 84 & 0.94 \\
\hline & Seasonal \& perennial & 90 & 7 & 81 & 7 & 9 & 7 & \\
\hline & Seasonal only & 995 & 80 & 887 & 80 & 108 & 80 & \\
\hline & Perennial only & 149 & 12 & 132 & 12 & 17 & 13 & \\
\hline & None & 172 & 12 & 146 & 11.5 & 26 & 16 & \\
\hline & Unknown & 14 & 1 & 13 & 1 & 1 & $<1$ & \\
\hline \multirow{4}{*}{ Allergic rhinitis severity } & Mild (ARIA 0) & 322 & 26 & 283 & 25 & 39 & 28 & 0.38 \\
\hline & Moderate (ARIA 1-3) & 655 & 52 & 585 & 53 & 70 & 51 & \\
\hline & Severe (ARIA 4) & 247 & 20 & 226 & 20 & 21 & 15 & \\
\hline & Unknown & 25 & 2 & 18 & 2 & 7 & 5 & \\
\hline \multirow{3}{*}{ Self-reported allergy history } & History of grass pollen allergy & 727 & 51 & 651 & 51 & 76 & 46 & 0.24 \\
\hline & History of eczema & 404 & 28 & 355 & 28 & 49 & 30 & 0.45 \\
\hline & History of food allergy & 231 & 16 & 211 & 17 & 20 & 12 & 0.16 \\
\hline
\end{tabular}

ER: Emergency Room. ARIA: Allergic Rhinitis and its Impact on Asthma (18). 
Table 3. Asthma management, control, and health care utilization, among patients with known current asthma by Emergency Room disposition.

\begin{tabular}{|c|c|c|c|c|c|c|c|c|}
\hline \multirow[t]{2}{*}{ ת } & & \multicolumn{2}{|c|}{$\begin{array}{l}\text { All ER patients } \\
\quad(\mathrm{n}=395)\end{array}$} & \multicolumn{2}{|c|}{$\begin{array}{l}\text { Discharged home } \\
\quad(\mathrm{n}=337)\end{array}$} & \multicolumn{2}{|c|}{$\begin{array}{c}\text { Admitted to } \\
\text { hospital } \\
(\mathrm{n}=58)\end{array}$} & \multirow[t]{2}{*}{$\mathrm{p}$ value } \\
\hline & & $\mathrm{n}$ & $\%$ & $\mathrm{n}$ & $\%$ & $\mathrm{n}$ & $\%$ & \\
\hline Uncontrolled Asthma & ACT $<20$ & 219 & 55 & 188 & 56 & 31 & 53 & 0.69 \\
\hline No regular preventer & No preventer use or preventer use $<5$ days per week & 267 & 68 & 230 & 68 & 37 & 64 & 0.28 \\
\hline No action plan & & 228 & 58 & 205 & 61 & 23 & 40 & 0.001 \\
\hline Health care utilisation & Non urgent GP visit & 175 & 44 & 147 & 44 & 28 & 48 & 0.35 \\
\hline & One night in hospital & 56 & 14 & 39 & 12 & 17 & 30 & $<0.001$ \\
\hline
\end{tabular}

GP: general practitioner, ER: Emergency Room, ACT: Asthma Control Test (19).

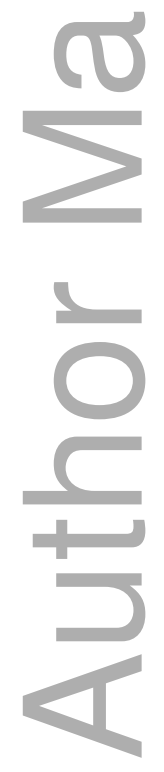

This article is protected by copyright. All rights reserved 
Table 4. Effect size of each variable on hospital admission for all patients.

\begin{tabular}{|c|c|c|c|c|}
\hline \multirow{3}{*}{ Characteristic } & \multicolumn{4}{|c|}{ Odds for hospital admission from Emergency room } \\
\hline & \multicolumn{2}{|c|}{ Unadjusted } & \multicolumn{2}{|c|}{ Adjusted for age \& sex } \\
\hline & OR $(95 \% \mathrm{CI})$ & $\mathrm{p}$ & OR $(95 \% \mathrm{CI})$ & $\mathrm{p}$ \\
\hline Age $(n=1435)$ & $1.010(1.002,1.019)$ & 0.02 & 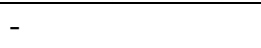 & \\
\hline Sex male $(n=1435)$ & $1.17(0.84,1.63)$ & 0.34 & - & \\
\hline Asian ethnicity ( $\mathrm{n}=1$ 113) & $0.63(0.40,0.99)$ & 0.04 & $0.59(0.38,0.94)$ & 0.02 \\
\hline Born in Australia $(n=1421)$ & $1.14(0.82,1.58)$ & 0.44 & $1.44(0.99,2.09)$ & 0.05 \\
\hline Current asthma $(\mathrm{n}=1052)$ & $1.92(1.30,2.85)$ & 0.001 & $1.87(1.26,2.78)$ & 0.002 \\
\hline Exposure outdoors $(n=1413)$ & $0.87(0.62,1.24)$ & 0.44 & $0.88(0.62,1.24)$ & 0.45 \\
\hline \multicolumn{5}{|l|}{ ARIA score $(n=1224)$} \\
\hline • 1 & $0.79(0.46,1.36)$ & 0.39 & $0.79(0.46 .1 .37)$ & 0.41 \\
\hline - 2 & $1.05(0.62,1.78)$ & 0.86 & $1.03(0.60,1.75)$ & 0.91 \\
\hline & $0.79(0.45,1.38)$ & 0.39 & $0.78(0.44,1.36)$ & 0.38 \\
\hline - 4 & $0.67(0.39,1.18)$ & 0.16 & $0.66(0.38,1.16)$ & 0.15 \\
\hline History of eczema $(n=1399)$ & $1.15(0.80,1.64)$ & 0.45 & $1.25(0.86,1.80)$ & 0.24 \\
\hline History of food allergy $(n=1407)$ & $0.71(0.43,1.16)$ & 0.16 & $0.73(0.45,1.20)$ & 0.22 \\
\hline $\begin{array}{l}\text { History of grass pollen allergy } \\
(n=1411)\end{array}$ & $0.82(0.59,1.14)$ & 0.24 & $0.80(0.57,1.11)$ & 0.17 \\
\hline Current smoking $(n=1396)$ & $1.00(0.56,1.79)$ & 0.99 & $0.96(0.54,1.73)$ & 0.89 \\
\hline Years living in Australia $(n=1402)$ & $1.02(1.01,1.03)$ & 0.001 & $1.22(1.01,1.03)^{a}$ & 0.001 \\
\hline
\end{tabular}

${ }^{a}$ Adjusted by sex. Asian: Chinese, Vietnamese, East or South-East Asian. ARIA: Allergic Rhinitis and its Impact on Asthma (18).

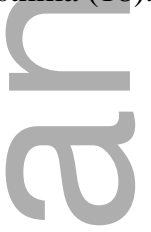

Table 5. Association between Asian ethnicity and hospital admission for the whole cohort, stratified by birth place.

\begin{tabular}{|c|c|c|c|c|}
\hline \multirow[t]{3}{*}{ Characteristic } & \multicolumn{4}{|c|}{ Odds for hospital admission from Emergency } \\
\hline & \multicolumn{2}{|c|}{$\begin{array}{l}\text { Born overseas } \\
\quad(\mathrm{n}=316)\end{array}$} & \multicolumn{2}{|c|}{$\begin{array}{c}\text { Born in Australia } \\
(\mathrm{n}=351)\end{array}$} \\
\hline & OR $(95 \% \mathrm{CI})$ & $\mathrm{p}$ & OR $(95 \% \mathrm{CI})$ & $\mathrm{p}$ \\
\hline \multicolumn{5}{|l|}{$\mathrm{p}$ for interaction $=0.008^{\beta}$} \\
\hline Age & $1.02(1.00,1.05)$ & 0.08 & $1.01(0.99,1.03)$ & 0.38 \\
\hline Sex male & $0.53(0.22,1.26)$ & 0.14 & $1.29(0.62,2.66)$ & 0.49 \\
\hline Asian ethnicity & $0.33(0.13,0.85)$ & 0.02 & $1.76(0.73,4.22)$ & 0.20 \\
\hline Current asthma & $2.58(1.04,6.41)$ & 0.04 & $1.35(0.68,2.69)$ & 0.39 \\
\hline Exposure outdoors & $2.07(0.88,4.86)$ & 0.09 & $0.52(0.25,1.12)$ & 0.09 \\
\hline \multicolumn{5}{|l|}{ ARIA score } \\
\hline$\bullet \quad 1$ & $0.64(0.15,2.82)$ & 0.55 & $0.95(0.37,2.42)$ & 0.91 \\
\hline - 2 & $0.55(0.13,2.22)$ & 0.39 & $2.18(0.84,5.66)$ & 0.10 \\
\hline - 3 & $0.80(0.20,3.25)$ & 0.75 & $1.11(0.38,3.24)$ & 0.84 \\
\hline - 4 & $1.63(0.50,5.35)$ & 0.41 & $0.84(0.27,2.59)$ & 0.75 \\
\hline History of eczema & $1.25(0.46,3.40)$ & 0.66 & $1.70(0.81,3.43)$ & 0.16 \\
\hline History of food allergy & $1.41(0.50,3.99)$ & 0.51 & $0.72(0.29,1.75)$ & 0.46 \\
\hline History of grass pollen allergy & $0.49(0.20,1.19)$ & 0.11 & $0.72(0.36,1.44)$ & 0.35 \\
\hline Current smoking & $0.70(0.08,5.96)$ & 0.74 & $1.25(0.34,4.69)$ & 0.73 \\
\hline
\end{tabular}

${ }^{\beta}$ OR for interaction between Asian ethnicity and born in Australia $=5.42$ (95\% CI: 1.56, 18.83)

Asian: Chinese, Vietnamese, East or South-East Asian. ARIA: Allergic Rhinitis and its Impact on Asthma (18). 
Table 6. Effect size of each variable on hospital admission, for patients with known current asthma.

\begin{tabular}{|c|c|c|c|c|}
\hline \multirow[t]{3}{*}{ Characteristic } & \multicolumn{4}{|c|}{ Odds for hospital admission from Emergency } \\
\hline & \multicolumn{2}{|c|}{ Unadjusted } & \multicolumn{2}{|c|}{ Adjusted with age \& sex } \\
\hline & OR $(95 \% \mathrm{CI})$ & $\mathrm{p}$ & OR $(95 \% \mathrm{CI})$ & $\mathrm{p}$ \\
\hline Age $(n=395)$ & $1.00(0.98,1.01)$ & 0.80 & - & \\
\hline Sex male $(n=395)$ & $1.56(0.87,2.79)$ & 0.13 & - & \\
\hline Asian ethnicity $(\mathrm{n}=328)$ & $0.65(0.31,1.36)$ & 0.25 & $0.61(0.29,1.31)$ & 0.20 \\
\hline Born in Australia $(n=394)$ & $1.00(0.57,1.76)$ & 0.99 & $0.94(0.49,1.80)$ & 0.85 \\
\hline Exposure outdoors $(n=393)$ & $0.86(0.47,1.57)$ & 0.62 & $0.84(0.46,1.54)$ & 0.58 \\
\hline \multicolumn{5}{|l|}{ ARIA score $(n=334)$} \\
\hline - 1 & $0.69(0.22,2.15)$ & 0.52 & $0.66(0.21,2.05)$ & 0.47 \\
\hline - 2 & $2.03(0.79,5.20)$ & 0.14 & $2.11(0.82,5.43)$ & 0.12 \\
\hline & $0.9(0.31,2.64)$ & 0.84 & $0.89(0.30,2.62)$ & 0.83 \\
\hline & $0.99(0.40,2.47)$ & 0.98 & $1.01(0.40,2.53)$ & 0.98 \\
\hline History of eczema $(n=385)$ & $1.47(0.83,2.62)$ & 0.19 & $1.47(0.81,2.68)$ & 0.20 \\
\hline History of food allergy $(n=386)$ & $0.32(0.13,0.76)$ & 0.01 & $0.31(0.13,0.76)$ & 0.01 \\
\hline $\begin{array}{l}\text { History of grass pollen allergy } \\
(n=387)\end{array}$ & $0.76(0.43,1.35)$ & 0.35 & $0.77(0.44,1.37)$ & 0.38 \\
\hline Current smoking $(\mathrm{n}=387)$ & $1.35(0.49,3.71)$ & 0.56 & $1.26(0.45,3.50)$ & 0.65 \\
\hline Have asthma action plan $(\mathrm{n}=387)$ & $2.52(1.42,4.45)$ & 0.002 & $2.75(1.51,5.00)$ & 0.001 \\
\hline ACT controlled $(n=386)$ & $1.12(0.64,1.97)$ & 0.69 & $1.07(0.60,1.91)$ & 0.81 \\
\hline *Non-urgent visit to GP $(n=380)$ & $1.31(0.74,2.33)$ & 0.35 & $1.31(0.73,2.33)$ & 0.36 \\
\hline *Urgent visit to GP $(\mathrm{n}=383)$ & $0.97(0.49,1.89)$ & 0.91 & $0.99(0.50,1.93)$ & 0.96 \\
\hline *Visit to hospital $(\mathrm{n}=384)$ & $1.76(0.98,3.16)$ & 0.05 & $1.77(0.98,3.20)$ & 0.06 \\
\hline $\begin{array}{l}\text { *Admitted to hospital for at least } \\
\text { one night }(n=379)\end{array}$ & $3.17(1.64,6.15)$ & 0.001 & $3.16(1.63,6.12)$ & 0.001 \\
\hline Years living in Australia $(n=389)$ & $1.01(0.99,1.03)$ & 0.24 & $1.01(0.99,1.03)$ & $0.17^{\mathrm{a}}$ \\
\hline
\end{tabular}

${ }^{a}$ Adjusted by sex. * In prior 12 months.

ARIA: Allergic Rhinitis and its Impact on Asthma (18), ACT: asthma control test (19).

Asian: Chinese, Vietnamese, East or South-East Asian.

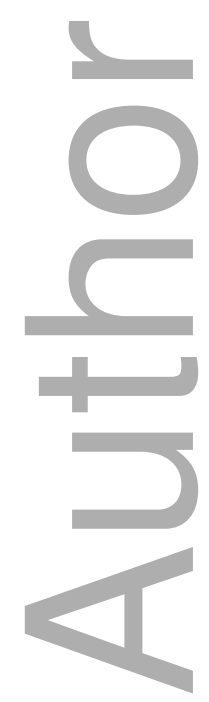




\section{University Library}

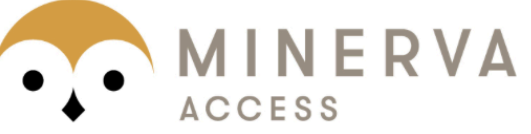

A gateway to Melbourne's research publications

Minerva Access is the Institutional Repository of The University of Melbourne

\section{Author/s:}

Hew, M;Lee, J;Susanto, NH;Prasad, S;Bardin, PG;Barnes, S;Ruane, L;Southcott, AM;Gillman, A;Young, A;Rangamuwa, K;O'Hehir, RE;McDonald, C;Sutherland, M;Conron, M;Matthews, S;Harun, N-S;Lachapelle, P;Douglass, JA;Irving, L;Langton, D;Mann, J;Erbas, B;Thien, $\mathrm{F}$

Title:

The 2016 Melbourne thunderstorm asthma epidemic: Risk factors for severe attacks requiring hospital admission

Date:

2019-01-01

\section{Citation:}

Hew, M., Lee, J., Susanto, N. H., Prasad, S., Bardin, P. G., Barnes, S., Ruane, L., Southcott, A. M., Gillman, A., Young, A., Rangamuwa, K., O'Hehir, R. E., McDonald, C., Sutherland, M., Conron, M., Matthews, S., Harun, N. -S., Lachapelle, P., Douglass, J. A. ,... Thien, F. (2019). The 2016 Melbourne thunderstorm asthma epidemic: Risk factors for severe attacks requiring hospital admission. ALLERGY, 74 (1), pp.122-130. https://doi.org/10.1111/ all.13609.

Persistent Link:

http://hdl.handle.net/11343/284640 